
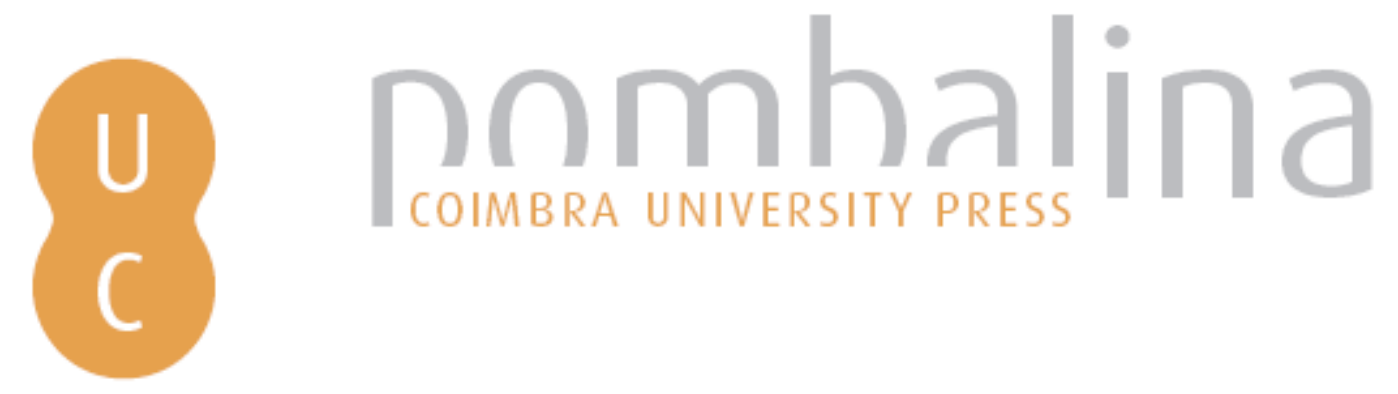

\title{
Drugs of abuse analysis in fatal victims of road traffic and labour accidents in the centre of Portugal between 1990 and 2007
}

\author{
Autor(es): $\quad$ Silva, R.; Costa, N.; Teixeira, H. M.; Proença, P.; Vidinha, J.; Mendonça, \\ M. C.; Corte-Real, F.; Vieira, D. N. \\ Publicado por: Imprensa da Universidade de Coimbra; International Academy of Legal \\ Medicine \\ URL
persistente: $\quad$ URI:http://hdl.handle.net/10316.2/31838 \\ DOI: $\quad$ DOI:http://dx.doi.org/10.14195/978-989-26-0173-1_49 \\ Accessed : $\quad$ 26-Apr-2023 13:45:44
}

A navegação consulta e descarregamento dos títulos inseridos nas Bibliotecas Digitais UC Digitalis, UC Pombalina e UC Impactum, pressupõem a aceitação plena e sem reservas dos Termos e Condições de Uso destas Bibliotecas Digitais, disponíveis em https://digitalis.uc.pt/pt-pt/termos.

Conforme exposto nos referidos Termos e Condições de Uso, o descarregamento de títulos de acesso restrito requer uma licença válida de autorização devendo o utilizador aceder ao(s) documento(s) a partir de um endereço de IP da instituição detentora da supramencionada licença.

Ao utilizador é apenas permitido o descarregamento para uso pessoal, pelo que o emprego do(s) título(s) descarregado(s) para outro fim, designadamente comercial, carece de autorização do respetivo autor ou editor da obra.

Na medida em que todas as obras da UC Digitalis se encontram protegidas pelo Código do Direito de Autor e Direitos Conexos e demais legislação aplicável, toda a cópia, parcial ou total, deste documento, nos casos em que é legalmente admitida, deverá conter ou fazer-se acompanhar por este aviso.
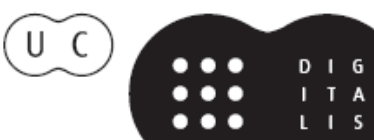


\section{Duarte Nuno Vieira Anthony Busuttil \\ Denis Cusack • Philip Beth}
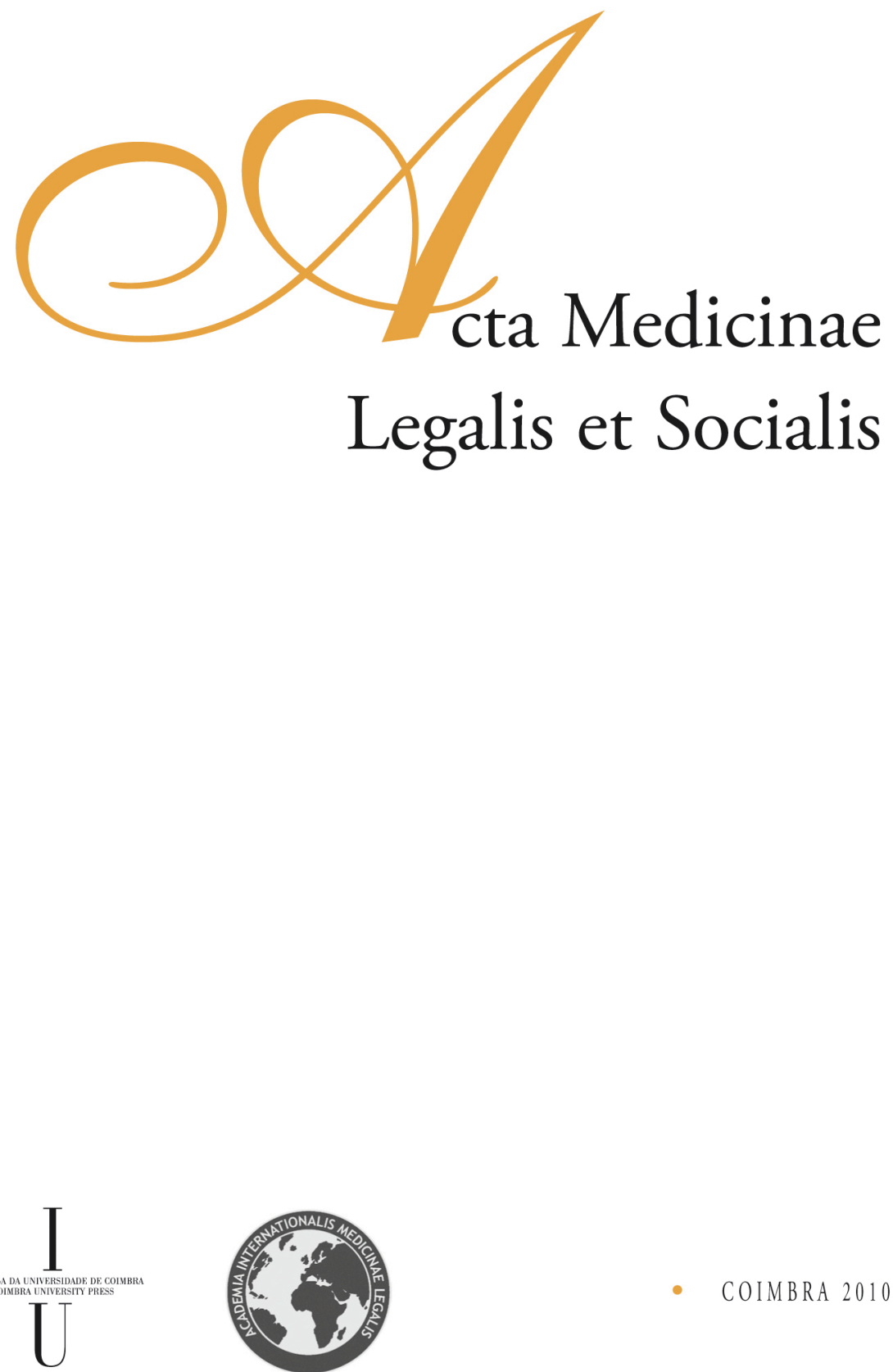
R. Silva ${ }^{3}$, N. Costa ${ }^{2}$, H. M. Teixeira ${ }^{1,4}$, P. Proença ${ }^{2}, J$. Vidinha ${ }^{2}$, M. C. Mendonça ${ }^{2,4}$, F. Corte-Real ${ }^{2,4}$, D. N. Vieira ${ }^{2,4}$

${ }^{1}$ North Branch of the National Institute of Legal Medicine, Oporto, Portugal

${ }^{2}$ Centre Branch of the National Institute of Legal Medicine, Coimbra, Portugal

${ }^{3}$ Figueira da Foz Legal Medicine Office, National Institute of Legal Medicine, Portugal

${ }^{4}$ Faculty of Medicine, University of Coimbra, Portugal

\title{
DRUGS OF ABUSE ANALYSIS IN FATAL VICTIMS OF ROAD TRAFFIC AND LABOUR ACCIDENTS IN THE CENTRE OF PORTUGAL BETWEEN 1990 AND 2007
}

\begin{abstract}
Driving under the influence of drugs is an issue of growing concern in the industrialized countries as a risk and a cause for road and labour accidents. The aim of this study was to assess the presence of drugs of abuse among drivers and workers involved in fatal accidents between January 1990 and December 2007, by presenting the requests and toxicological results of corresponding autopsies, from the Pathology Service of the Centre Branch of the National Institute of Legal Medicine and from a Legal Medicine Office. In the Forensic Pathology Service, between 1990 and 2007, a total of 3095 autopsies on road traffic accidents victims and 261 on labour accidents victims were performed and 33628 , respectively, in the office. In both cases, few requests and analyses of drugs of abuse were performed, emphasising the fact that the major percentage of the accidents involved individuals aged between 21 and 30 years-old, ages where the consumption is more often. Nevertheless, from the 261 victims of labour accidents autopsied, only 7 were subject of drug analysis, all with negative results.
\end{abstract}

Keywords: Drugs of abuse; road traffic and labour accidents.

\section{Introduction}

During the last years, driving under the influence of drugs other than alcohol has gained considerable attention as a problem to road traffic and labour accidents [1]. Increasing occurrence of driving under influence of non-alcohol drugs has been reported from several countries [2-4].

This paper presents a retrospective analysis of the toxicological investigation on biological samples from fatally injured drivers, between January 1990 and December 2007, to determine the role, if any, of ethanol amongst fatal road traffic accidents.

\section{Material and Methods}

This study has been carried out by the National Institute of Legal Medicine of Portugal. The target population consisted of drivers killed in road and labour accidents. The data available in each case was: year, sex, age and drugs concentrations. 
The authors present the requests and consequent drug results of the road traffic accidents autopsies and on fatal victims of labour accidents performed from 1990 and 2007 in the Pathology Service of the Centre Branch of the National Institute of Legal Medicine (NILM) and performed from April 2001 (open date of the office) and 2007 in the Legal Medicine Office of Figueira da Foz. All drug analyses were performed in the Forensic Toxicology Laboratory of the Centre Branch of the NILM.

Several variables were studied and all the pertinent data was registered, separated and statistically treated with the SPSS program (Statistical Package will be Social Sciences).

\section{Results and Discussion}

Driving is a very complex task, during which the drivers continually receives information, analyzes it and react. The different steps involved in the practice of driving involve functions that are interrelated in a very narrow. The whole process is, likewise, closely related to the knowledge of the driver and his attitude quickly reflected in their behaviour while driving.

In the Forensic Pathology Service a total of 9409 autopsies were performed between 1990 and 2007, 3095 on road traffic accidents victims and 261 on labour accidents victims, $78 \%$ and $97 \%$ in male victims, respectively (Fig. 1 ).

We found that the most troubling months in which there was a higher number of autopsies in road traffic accidents was the month of August for the Branch, but considerably different for the LMO, which had the highest number of cases in October since this could be justified by the increased movement on Portuguese roads due to holidays and tourism, family visiting emigrants abroad, or even due to sleep disturbance, especially during the afternoon, usually after lunch.

For the LMO, we can only assume that accidents occur mainly in October, probably due to unusual weather conditions, the early days of rain and consequent association of roads with oil and water, resulting in imminent risk of accident.

Drugs of abuse analysis were requested in only $4 \%$ of the road traffic accident cases and in 3\% of the labour accidents (Figs. 2, 3).

In the Legal Medicine Office, from April 2001 to 2007, 1219 autopsies were performed, 336 to car accident victims, $82 \%$ men, and 28 to labour victims, with only one female victim (Fig.4).

In the car accident fatal deaths, $17 \%$ included drugs of abuse analysis, as well as $32 \%$ of the labour accidents (Figs. 5, 6).

As expected, the increase of the consumption of illicit substances in our country led to a growing concern, not only to their effect on health, but to all risk behaviours and deviant behaviour of the consumer [5]. Therefore, and as mentioned before, with the introduction of specific legislation in Portugal, concerning driving under the influence of alcohol and psychotropic substances, there is a greater awareness by all the experts with regard to the obligation to request drugs of abuse in cases of fatal car accidents. It is important to emphasise the fact that the introduction of a new law in 2007 also increased the requests, since before that only drivers involved in road accidents (seriously injured or death) would be subject to the screening of drugs of abuse. Currently, drivers can be monitored by the mere fact that law enforcement agents suspect the consumption of such substances. This was indeed a very important measure and valid introduced in our country. 
Note, however, that despite the positive result of only about $9.5 \%$, it is not possible to conclude that there is a low consumption of such substances when combined with driving. However, as mentioned before, this research was performed in only $4.4 \%$ (Branch) and $17.3 \%$ (LMO) of autopsied cases of traffic accident, leaving open all other drivers where such research was not even considered.

Important to add to this the fact that the greatest percentage of cases where no request was made for drugs focused on individuals aged from 21 to 30 years-old, corresponding to ages where the consumption of such substances have a greater effect.

From the road accident cases analyzed, 9 drugs were positive mainly in men (84\%) aged between 21 and 30 years-old, being the opiates (47.1\%) and canabinoids (50\%) the most encountered groups.

Portuguese law concerning labour monitoring significantly addresses the problem of alcohol and psychotropic substances, because workers can, by law, be subject to a random check by the employer at any time of their activity. However, its review or determination in postmortem cases is not fully informed or legislated, in relation to how to act specifically in labour accident autopsies. Accordingly, the discrepancy of results concerns the practice carried out by experts who, more and more, are being aware and scientifically instructed to further research and evaluation of substance influence in labour accidents and consequent legal aspects implicated, such as life insurance, for example.

As already mentioned before, once again, for labour accidents, few requests of drugs of abuse were performed and only 9 of the 28 labour accidents victims were subject of drug analysis, all with negative results. From the total 58 requests (17\%) for drugs in the road traffic victims, 5 were positive, mainly for cannabinoids and cocaine.

It is, however, extremely important to emphasize the fact that $96 \%$ of the cases autopsied in the Pathology Service did not include the drug analysis request, 21\% with individuals aged between 21 and 30 years-old, ages where the consumption is more often. Nevertheless, from the 261 victims of labour accidents autopsied, only 7 were subject of drug analysis, all with negative results (Fig. 7).

Once again, in the Legal Medicine Office, $83 \%$ of the cases did not include the drug analysis request, $41.7 \%$ with individuals aged between 21 and 30 years-old, ages where the consumption is more often (Fig. 8).

The requests for drugs of abuse analysis in labour accident deaths were substantially reduced, taking into account the potential that these substances can have through the cognitive and psychomotor skills of an individual, which negatively affects their job performance and leading inevitably to accidents [6]. Note that, from a total of 261 accidents recorded in the Branch, only 7 included the requests of drugs of abuse.

Also in the LMO, only 9 requests for drugs were performed on the 28 victims of labour accidents. It can be perfectly understood since they were cases of individuals aged over 55 years. It should be noted, however, that, as mentioned above, both the Branch and the LMO, had high rates of accidents in people aged between 21 and 40 years.

We observed that none of the 16 cases examined were positive for drugs of abuse. It is important to state that in 18 years analyzed for the delegation, there were only 261 autopsies on labour accident victims and only 28 victims in the 7 years analyzed in LMO. However, only these 289 cases included 16 drug analyses and, given the shortage of requests, that information is clearly not statistically significant, impossible to predict the consumption of drugs of abuse in labour accidents. 


\section{Conclusion}

Drugs of abuse can be defined as all chemical substances, psychotropic, which illicit consumption occurs more or less compulsively. Driving under the influence of drugs is an issue of growing concern in the industrialized countries as a risk and a cause for road and labour accidents.

The most common drugs (other than alcohol) found in fatally cases have been cannabis, benzodiazepines, amphetamine-like stimulants and opiates [7].

For road accidents, there were almost no requests of drugs of abuse, corresponding to only $4.4 \%$ of the cases in the Centre Branch and $17.3 \%$ in the LMO.

The requests for drugs of abuse analysis in labour accident deaths were substantially reduced: from a total of 261 accidents in the Branch, only 7 included this request. The same was observed for the LMO, where only 9 requests for drugs were performed on 28 victims of labour accidents autopsies.

It is easy to conclude that there are few requests for drugs of abuse in both car and labour fatal accidents. Traffic and workplace safety is a major concern for society. Aside from alcohol, there are other sources of impairment, like the illicit drugs, that may be related to accident risk. However, whereas the evidence of impairment from alcohol and fatigue has been sufficiently demonstrated to provide a basis for some policies, the evidence that certain classes of drugs may impair and, thereby, increase accident risk, is inconclusive. In contrast to alcohol, reliable epidemiologic data are not available and must be done, for e.g., by the increasing of drugs analysis requests in cases of road traffic and labour accidents.

\section{References}

1. GIER JJ. Road traffic and illicit drugs, review of investigation of prevalence of illicit drugs in road traffic in different European countries, co-operation group to combat drug abuse and illicit trafficking in drugs (Pompidou group). ISBN-90-804577-1-X, 1998.

2. AUGSBURGER M, RIVIER L. Drug and alcohol among suspected impaired drivers in Canton de Vaud (Switzerland). Forens Sci Int, 85:95-104, 1997.

3. CHRISTOPHERSEN AS, MORLAND J. Drugged driving, a review based on the experience in Norway, Drug Alcohol Depend, 47:125-135, 1997.

4. SEYMORE A, OLIVIER JO. Role of drugs and alcohol in impaired drivers and fatally injured drivers in the Strathclyde police region of Scotland, 1995-1998, Forens Sci Int, 103:89-100, 1999.

5. DRUMMER, O.H., JIM GEROSTAMOULOS, HELEN BATZIRIS, MARK CHU, JOHN CAPLEHORN, MICHAEL D. ROBERTSON AND PHILIP SWANN (2004). The involvement of drugs in drivers of motor vehicles killed in Australian road traffic crashes. Acc. Anal. \& Preven., 36(2):239-48.

6. POLLACK, E.S.; FRANKLIN, GARY M.; FULTON-KEHOE, DEBORAH; CHOWDHURY, RISANA (1998). Risk of job-related injury among construction laborers with a diagnosis of substance abuse. J. Occ. \& Environ. Med., 40(6):573-7.

7. SKURTVEIT S, ABOTNES B, CHRISTOPHERSEN AS. Drugged drivers in Norway with benzodiazepine detections. Forens Sci Int, 125:75-82, 2002. 


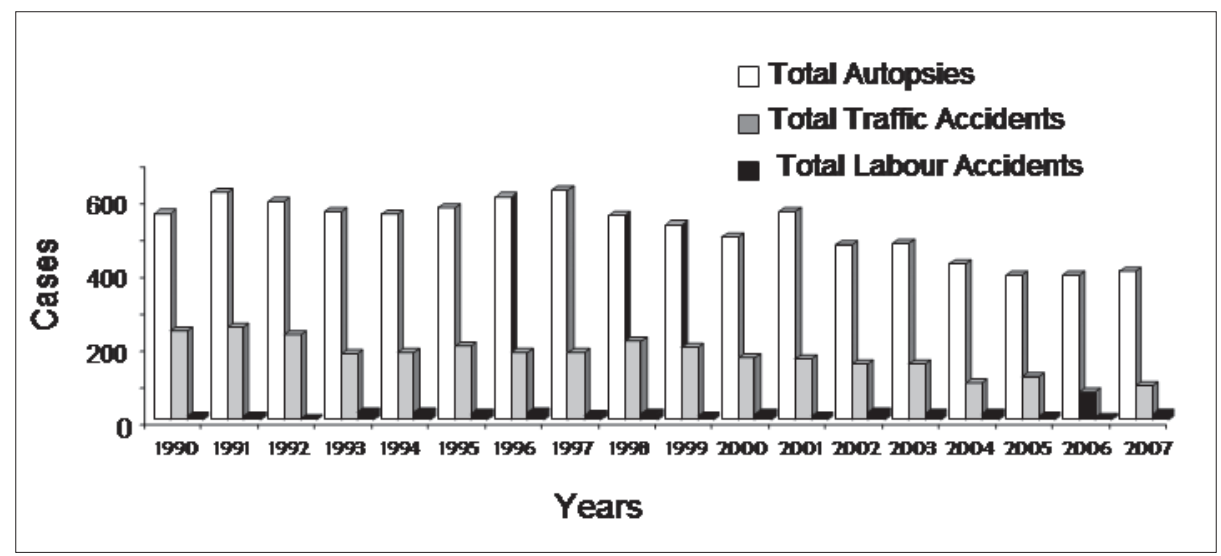

Figure 1 - Number of Traffic \& Labour Accidents in the autopsies performed in the forensic pathology service between 1990 and 2007.

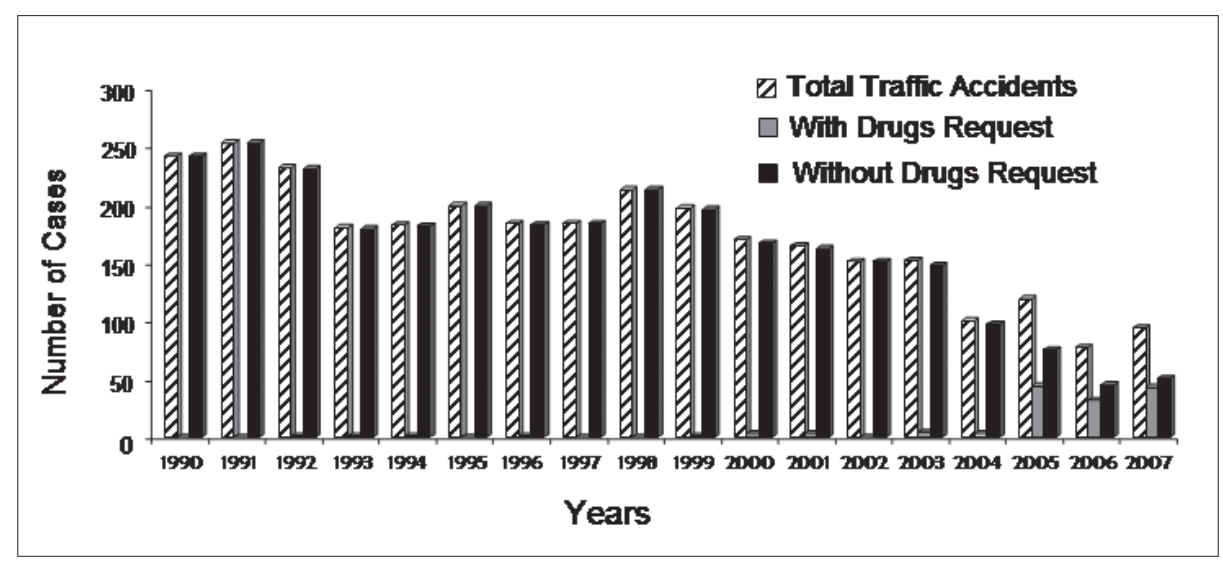

Figure 2 - Number of Traffic Accidents with and without Drugs request (in the forensic pathology service).

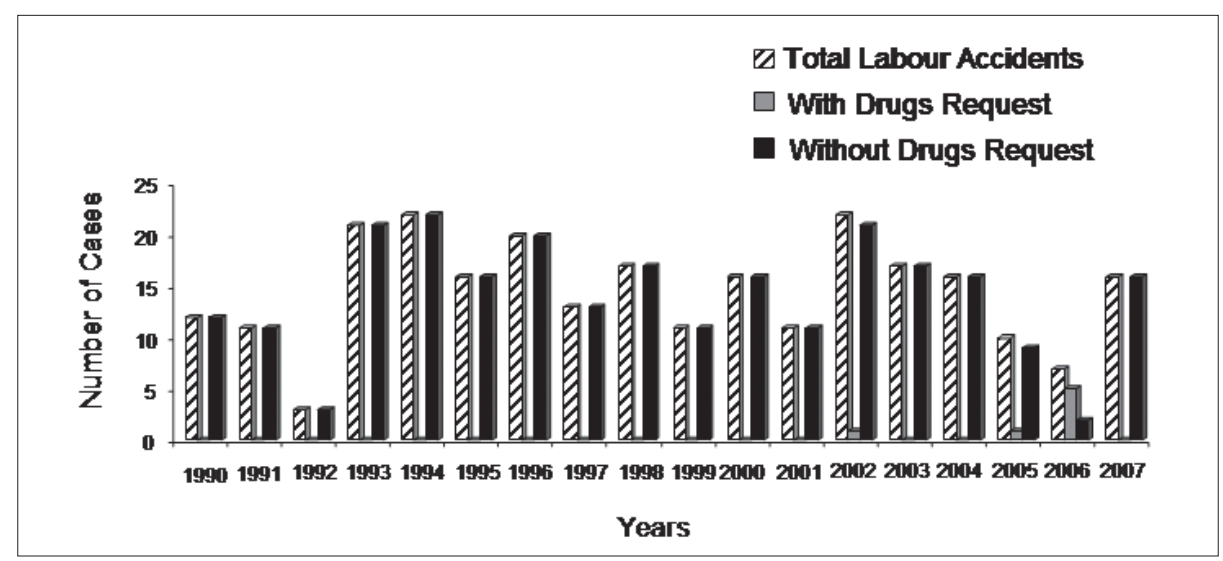

Figure 3 - Number of Labour Accidents with and without Drugs request

(in the forensic pathology service). 


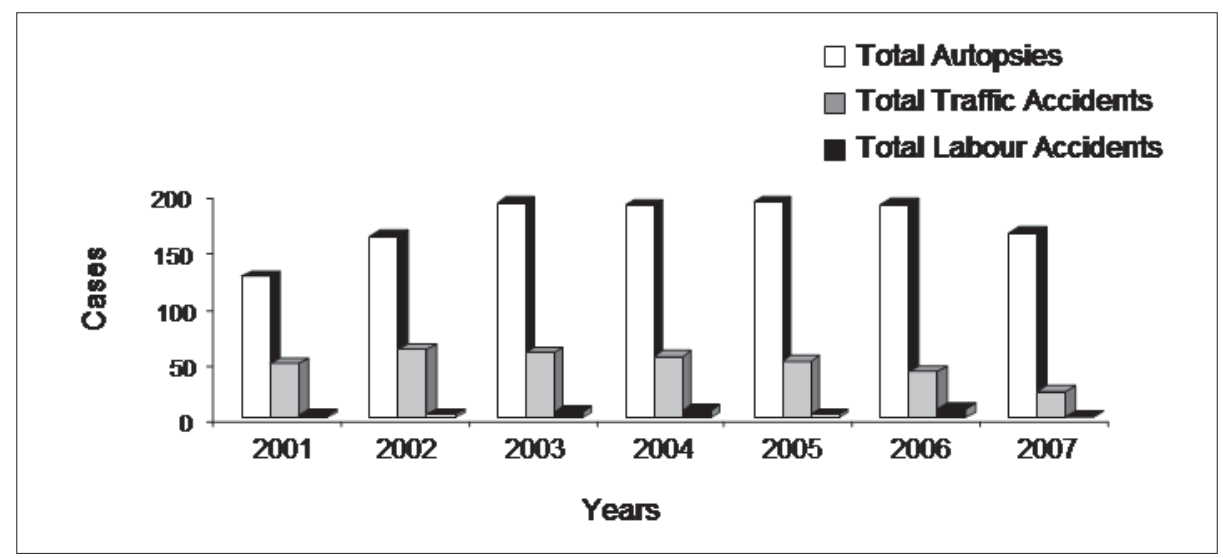

Figure 4 - Number of Traffic \& Labour Accidents in the autopsies performed in the Legal Medicine office between 2001 and 2007.

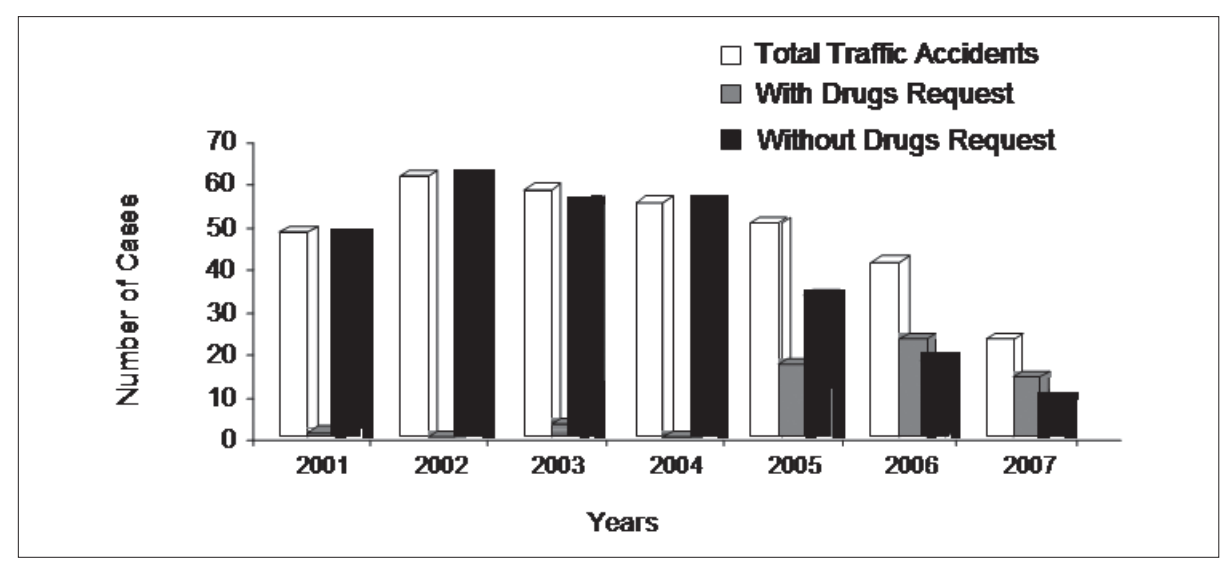

Figure 5 - Number of Traffic Accidents with and without Drugs request (in the Legal Medicine Office of Figueira da Foz).

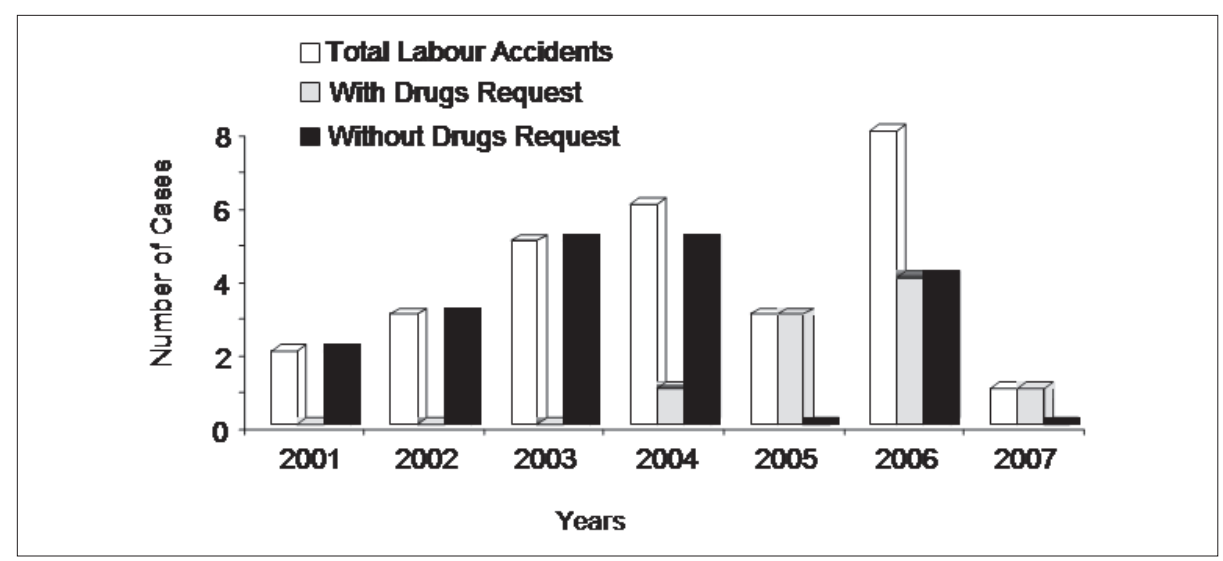

Figure 6 - Number of Labour Accidents with and without Drugs request (in the Legal Medicine Office of Figueira da Foz). 


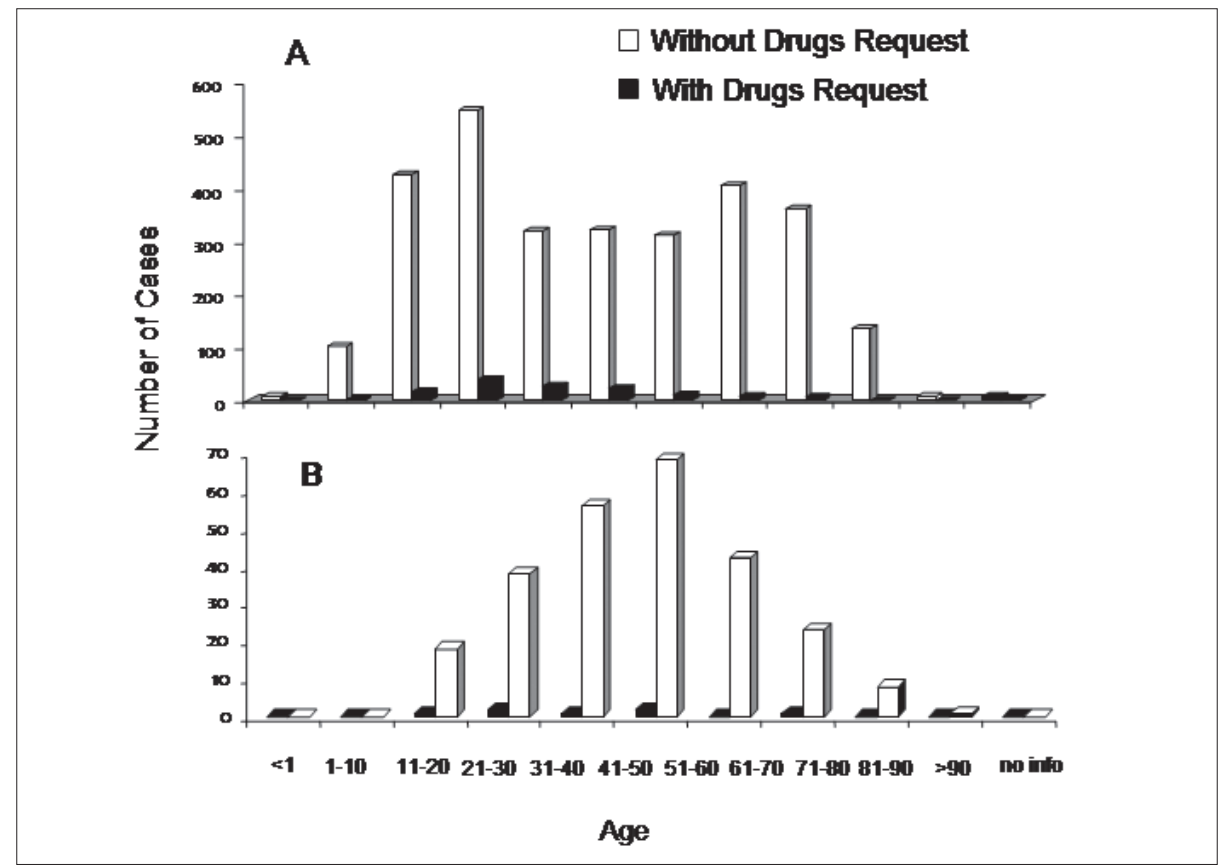

Figure 7 - Number of Traffic Accident (A) and Labour Accident (B) cases with/without drugs request per age (in the forensic pathology service).

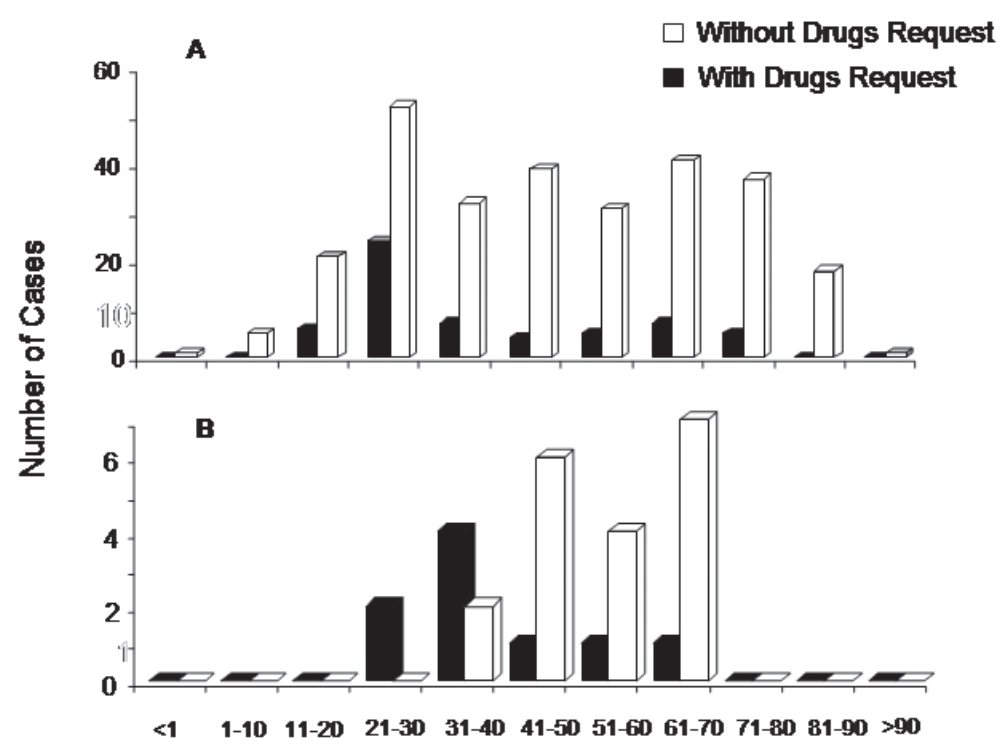

Age

Figure 8 - Number of Traffic Accident (A) and Labour Accident (B) cases with/without drugs request per age (in the Legal Medicine Office of Figueira da Foz). 